\title{
The Effect of Work Engagement and Mindfulness on Organizational Behavior
}

\author{
Zülbiye Kaçay (Corresponding author) \\ Department of Management, Faculty of Sports Sciences \\ Çanakkale Onsekiz Mart University, Çanakkale, Turkey \\ Tel: 90-542-237-61-19Ｅ-mail: zzkacay@gmail.com
}

\begin{abstract}
Nuri Berk Güngör
Department of Physical Education and Sport, Faculty of Sports Sciences

Karamanoğlu Mehmet Bey University, Karaman, Turkey
\end{abstract}

Tel: 90-505-655-67-99 E-mail: nuriberkgungor@gmail.com

Fatih Yenel

Department of Management, Faculty of Sports Sciences

Gazi University, Ankara, Turkey

Tel: 90-312-202-35-00Ｅ-mail: fyenel@gazi.edu.tr

\author{
Fikret Soyer \\ Department of Management, Faculty of Sports Sciences \\ Balıkesir University, Balıkesir, Turkey \\ Tel: 90-532-547-89-82Ｅ-mail: fikretsoyer@gmail.com
}

Received: November 26, 2020

Published: December 31, 2020

doi:10.5296/jei.v6i2.17975
URL: https://doi.org/10.5296/jei.v6i2.17975

Accepted: December 24, 2020 


\section{Abstract}

The aim of this study was to determine the effect of work engagement and mindfulness on positive organizational behavior. A total of 203 participants, 73 females $(36.0 \%)$ and 130 males $(64.0 \%)$ working in different positions and levels in the Ministry of Youth and Sports in September 2020 participated in the study voluntarily. The Utrecht Work Engagement Scale, Mindfulness Scale, Positive Organizational Behavior Scale were used in the study. In the analysis of the data; Skewness and Kurtosis, multiple linear regression analysis, Pearson Moments Multiplication Correlation Coefficient, Multiple Linear Regression Analysis and descriptive statistics were used. The work engagement, mindfulness levels of the participants were high and their positive organizational behavior levels were at the acceptable level. It was determined that there was a significant relationship between all the scales and their sub-dimensions. In addition, it was concluded that $37 \%$ of optimism, $21 \%$ of psychological resilience, $34 \%$ of hope and $47 \%$ of self-efficacy were explained by vigor, absorption, concentration and mindfulness.

Keywords: positive organizational behavior, work engagement, mindfulness, employee

\section{Introduction}

Today, organizations try to get out of the war of existence with the least damage. They have to cope with both increasing quality and quantity, and keep up with the rapidly globalizing world and maintain its existence. Considering this point of view, organizations have to be effective and efficient in order to obtain a continuous competitive advantage. To be effective and efficient organizations depend on the quality of human capital, which is the building block of organizations, in terms of knowledge, skills and experience. Because from its establishment to management, from service production to marketing, human efficiency and productivity come to the fore at every level of the organization. Therefore, employee behavior and positive psychology, which examines employee behavior and their positive aspects and virtues, comes to the fore as one of the most important factors that can affect efficiency, productivity and performance in the organization.

The field of Organizational Behavior deals with the interaction, communication and behavior patterns of the individuals with each other and the groups they belong to, how and why these behaviors are displayed and what kind of relationship they have with the organizational structure (Koçel, 1999: 357). Just as the organization and its environment are constantly changing and developing with the globalizing world, the interests, needs and expectations of the people that form it are changing and increasing in the same direction.

The field of organizational behavior is a versatile and interdisciplinary science because it is related to many disciplines dealing with human behavior (Robbins \& Judge, 2010; Gürbüz \& Sığr1, 2015: 3). On the other hand, the individual can neither be considered separately from the organization nor can the organization be the subject of study alone. In this respect, individuals, groups, and organizational factors are within the scope of organizational behavior and study (Mowday \& Sutton, 1993: 198; Sims, 2002: 2; Griffin \& Moorhead, 2011: 3). What organizational behavior is, can be easily expressed when looking at the word 
equivalents contained in the concept. Accordingly, the organization is a system that people set up to achieve certain goals and the behaviors are the attitudes and actions of individuals that make up organizations. Organizational behavior can be defined as a discipline that examines and understands the behaviors of the individuals that make up the organization in the working environment and aims to increase the performance of the organization by making predictions about future behaviors. Luthans's statement, "Organizational behavior is directly related to understanding, predicting and controlling human behavior in organizations" confirms this definition (Kırpık, 2020: 13). According to another definition, organizational behavior is a field study that examines the actions of individuals who form an organization systematically and practically (Bratton, 2015: 4), investigates and tries to understand the cause (Kaygin \& Kosa, 2020).

Positive organizational behavior, which focuses on what is right and what should be and how these behaviors and virtues can be developed rather than what is wrong in the individual, is a trend that is accepted as the reflection of positive psychology on the organizational climate (Güler, 2009: 122). The aim is to increase the contribution to the success of the organization by ensuring to benefit from the positive psychological capitals such as optimism, hope, self-efficacy and creativity at the highest level. The difference in this trend from classical organizational behavior is that it focuses on the improvable and manageable features of the employees (Luthans et al., 2008: 220).

On the other hand, in a world that is getting more complex and uncertain, even the direction of change is unpredictable; the organizations maintain their success and sustainability by the presence of employees who are open to change and innovation, sensitive, consciously aware and dedicated to their work.

We are exposed to many stimuli during the day, and sometimes it is as if we are not the subject or object of many behaviors (Brown \& Ryan, 2003). However, mindfulness refers to being able to focus and be aware of what is happening around us, just like selective attention or selectivity in perception. The concept, which dates back to ancient times, is a part of the Buddhist tradition and has been used in many fields (Brown et al., 2007). He is a Buddhist monk who took the concept outside the religious dimension and worked with concepts such as mental clarity, balance, and self-control (Thera, 2008). Conscious awareness refers to focusing on the moment (now) without judgment (Kabat-Zinn, 2005). Three components of mindfulness can be mentioned. These are attention, intention, and attitude. While attention is noticing and letting in certain stimuli among many, intention; creates a justification for the attention component and attitude determines how to behave (Aktepe \& Tolan, 2020: 534). According to the definition in the field of psychology; It is the state of awareness that enables the management of various mental processes that cause emotional problems and maladaptive behaviors (Bishop et al., 2004). The emotions and thoughts revealed by this awareness can be removed from the focus of the mind and the emotional problems shaped by the thoughts can be alleviated (Gilbert, 2005). In addition to the different characteristics affected by a high level of mindfulness (Güngör, Kurtipek, \& Tolukan, 2020; Kurtipek, Güngör, Esentürk, \& Tolukan, 2020), there are many positive business behaviors and consequences that mindfulness has positively influenced, and it is particularly notable for its direct contribution 
to performance in service sectors (Dane \& Brummel, 2013; Moore \& Malinowski, 2009).

The concept of work engagement, first introduced by Kahn in 1990, refers to the employees' efforts to fulfill their duties physically, emotionally, spiritually in short with all their selves (Schaufeli, Salanova, Gronzález-Romá, \& Bakker, 2002).

The goal of sports organizations is basically to determine the sports need of the society and meet this need in order to create a more vibrant, healthier and dynamic generation physically, spiritually, emotionally and morally. In this context, its social contribution as well as its individual cannot be ignored (Kaçay \& Soyer, 2020: 3). From this point of view, it is important that the human capital, which will lead the organization to success in line with its goals, should engage with his work, carefully examine what is happening around him and reflect this on his behaviors. The aim of the study was to determine the effect of work engagement and mindfulness on the positive organizational behaviors of the personnel of the General Directorate of Sports. Also to make suggestions that will contribute to the regulation of organizational behavior based on the research findings.

Highlights of this study are given below

- Work engagement has a positive effect on organizational behavior.

- Mindfulness has a positive effect on organizational behavior.

- All the variables have a relationship with each other.

\section{Method}

This section includes information about the research model, study group, data collection tool and data analysis.

\subsection{Research Model}

This research has been designed in a descriptive structure and the relational scanning model has been used. Relational survey models are research models that aim to determine the presence and/or degree of co-change between two or more variables (Karasar, 2013). Work engagement, mindfulness and organizational behavior levels of the employee were measured through surveys and relationships among these variables were determined.

\subsection{Participants}

The study group of the research comprised of 73 females $(36.0 \%)$ and 130 males $(64.0 \%)$ who work in different positions and levels in the Ministry of Youth and Sports in September 2020. While forming the group of the study, the purposeful sampling method and easy sampling method were used. The scales were administered to all the participants. While 21 of the participants were graduates of high school (10.3\%), 149 (73.4\%) were undergraduate, 31 $(15.3 \%)$ were master's degree and $2(1.0 \%)$ were doctoral program graduates. Also; 72 (35.5\%) were officers, $28(13.8 \%)$ were managers, 74 (36.5\%) were trainers and $29(14.3 \%)$ were in the sports training specialist staff. The average tenure of the participants was $9.38 \pm 7.54$ and the average age was $36.87 \pm 7.58$. 


\subsection{Data Collection Tools}

In the research, along with the personal data collection form, Work Engagement Scale, Mindfulness and Positive Organizational Behavior Scales were used.

\subsubsection{Utrecht Work Engagement Scale}

In the research, the "Utrecht Work Commitment Scale" developed by Schaufeli and Bakker (2003) was used. The scale has a 7-point structure and consists of 17 items in total. The sub-dimensions of the scale were expressed as "vigor", "assimilation" and "concentration". The lowest score that can be obtained from the scale is 17 and the highest score is 119. It can be stated that the higher the score obtained from the scale, the higher the level of work engagement. The internal consistency coefficients obtained from the data set are .92 for the whole scale; 87 for vigor sub-dimension, .76 for assimilation sub-dimension and .88 for concentration sub-dimension.

\subsubsection{Mindfulness Scale}

It was developed by Brown and Ryan (2003) and adapted into Turkish by Özyeşil, Arslan, Bıçak, and Deniz (2011). The scale, comprised of 15 items in total, represents a 6-point Likert structure. Higher scores on the scale indicate an increased level of conscious awareness. In the original form of the scale, the internal consistency coefficient is .80 . The Cronbach Alpha internal consistency coefficient obtained from the data set used in the study was determined as .87 .

\subsubsection{Positive Organizational Behavior Scale}

The scale developed by Luthans et al. (2007) consists of 24 items and 4 sub-dimensions. Sub dimensions are "optimism", "resilience", "hope" and "self-efficacy". Internal consistency coefficients in the original form of the scale were .93 for the whole scale, $.89, .89, .88, .89$ for the sub-dimensions, respectively. The internal consistency coefficients obtained from the data set were determined as .90 for the whole scale, $.82, .79, .78$ and .80 for the sub-dimensions, respectively. 5395734486

\subsection{Data Analysis}

In the analysis of the data, 15 participant forms that had extreme values in the data set were excluded from the research. Afterward, Skewness and Kurtosis values were examined by looking at the significant result of the Shapiro-Wilk test in order to determine whether the data set met the assumptions of normality. These values for the measurement tools used in the study are between -1.5 and +1.5 . Therefore, it has been determined that the data have a normal distribution (Tabachnick \& Fidell, 2013). The normality and linearity assumptions of the data set were examined and the compatibility with regression analysis was investigated. For this reason, the scattering diagram created showed the existence of a linear relationship. Therefore, the availability of multiple linear regression analysis for the data set was determined. Pearson Moments Multiplication Correlation Coefficient (r) was used to determine the relationship between the variables used in the study. The effect of participants' work engagement and mindfulness on organizational behavior was demonstrated using 
Multiple Linear Regression Analysis. However, descriptive statistics were used for the average scores obtained from the scales. In the research, SPSS 22 Package Program was used in addition to the Excel database.

\section{Results}

In this section, findings obtained by analyzing the data are presented.

Table 1. Average scores of the participants in the work engagement scale

\begin{tabular}{|l|l|l|l|l|l|}
\hline Scales & $\mathrm{N}$ & Min. & Max. & $\overline{\mathrm{x}}$ & $\mathrm{S}$ \\
\hline Vigor sub-dimension & 203 & 3.00 & 7.00 & 5.63 & .95 \\
\hline Absorption sub-dimension & 203 & 2.00 & 7.00 & 5.79 & .95 \\
Concentration sub-dimension & 203 & 2.83 & 7.00 & 5.30 & 1.05 \\
\hline Work Engagement Scale & 203 & 3.18 & 7.00 & 5.56 & .86 \\
\hline
\end{tabular}

The average score the participants got from the Work Engagement Scale was $(\bar{x}=5.56)$, from the vigor, absorption, concentration sub-dimensions were $(\overline{\mathrm{x}}=5.63),(\overline{\mathrm{x}}=5.79),(\overline{\mathrm{x}}=5.30)$ respectively.

Table 2. Average scores of the participants in organizational behavior and mindfulness scales

\begin{tabular}{|l|l|l|l|l|l|}
\hline Scales & $\mathrm{N}$ & Min. & Max. & $\overline{\mathrm{x}}$ & $\mathrm{S}$ \\
\hline Optimism sub-dimension & 203 & 2.00 & 5.00 & 3.80 & .67 \\
\hline Resilience sub-dimension & 203 & 2.17 & 5.00 & 3.49 & .54 \\
Hope sub-dimension & 203 & 2.17 & 5.00 & 4.06 & .53 \\
Self-efficacy sub-dimension & 203 & 1.50 & 5.00 & 3.89 & .60 \\
\hline P. Organizational Behavior Scale & 203 & 2.17 & 5.00 & 3.81 & .49 \\
\hline Mindfulness Scale & 203 & 1.93 & 5.87 & 4.33 & .79 \\
\hline
\end{tabular}

The average score the participants got from the Mindfulness Scale was determined as ( $\overline{\mathrm{x}}=$ 4.33), from the Positive Organizational Behavior Scale was $(\overline{\mathrm{x}}=3.81)$. Also, the average scores got from the sub-dimensions of Positive Organizational Behavior (optimism, resilience, hope, self-efficacy) were determined as $(\overline{\mathrm{x}}=3.80),(\overline{\mathrm{x}}=3.49),(\overline{\mathrm{x}}=4.06)$ and $(\overline{\mathrm{x}}=3.89)$ respectively. 


\section{Macrothink}

Table 3. Investigation of the relationship between variables with the Pearson product moment correlation

\begin{tabular}{|l|l|l|l|l|l|l|l|l|}
\hline & VI & AB & CO & OP & RE & HO & SE & M \\
\hline & & & & & & & & \\
\hline VI & 1 & & & & & & & \\
\hline AB & $.64^{* *}$ & 1 & & & & & & \\
\hline CO & $.63^{* *}$ & $.63^{* *}$ & 1 & & & & & \\
\hline OP & $.56^{* *}$ & $.31^{* *}$ & $.46^{* *}$ & 1 & & & & \\
\hline RE & $.43^{* *}$ & $.26^{* *}$ & $.35^{* *}$ & $.61^{* *}$ & 1 & & & \\
\hline HO & $.56^{* *}$ & $.39^{* *}$ & $.48^{* *}$ & $.64^{* *}$ & $.54^{* *}$ & 1 & & \\
\hline SE & $.64^{* *}$ & $.29^{* *}$ & $.36^{* *}$ & $.62^{* *}$ & $.54^{* *}$ & $.62^{* *}$ & 1 & \\
\hline M & $.37^{* *}$ & $.17^{*}$ & $.09^{*}$ & $.32^{* *}$ & $.22^{* *}$ & $.14^{*}$ & $.43^{* *}$ & 1 \\
\hline
\end{tabular}

Note. $\mathrm{VI}=$ Vigor; $\mathrm{AB}=$ Absorption $; \mathrm{CO}=$ Concentration; $\mathrm{OP}=$ Optimism; $\mathrm{RE}=$ Resilience; $\mathrm{HO}=$ Hope.

$\mathrm{p}<.01$.

When Table 3 was examined; A positive and moderate relationship was determined between "vigor" (VI) and "optimism" (OP), "psychological resilience" (RE), "self-efficacy" (SE) and "mindfulness" (M). A positive and moderate level relationship was determined between "absorption" ( $\mathrm{AB})$, "optimism" (OP) and "hope" (HO). A low-level positive correlation was found with "psychological resilience", "self-efficacy" and "mindfulness". A positive and moderate relationship was determined between "concentration" and "optimism", "resilience", "hope" and "self-efficacy". Also; It has been determined that there was a positive and low-level relationship between "concentration" and "mindfulness". Between "mindfulness", "optimism" and "self-efficacy" a positive and moderate level; A low-level positive relationship between mindfulness, "psychological resilience" and "hope" were determined. 
Table 4. Results of Multiple Regression Analysis Predicting Organizational Behavior

\begin{tabular}{|c|c|c|c|c|c|c|}
\hline Variables & & Standardize $\beta$ & Standard Error & Critical Rate & $\mathrm{p}$ & $\mathrm{R}^{2}$ \\
\hline Vigor & \multirow{4}{*}{ Optimism } & .42 & .06 & 4.86 & .00 & \multirow{4}{*}{.37} \\
\hline Absorption & & -.17 & .06 & -2.17 & .03 & \\
\hline Concentration & & .29 & .05 & 3.60 & .00 & \\
\hline Mindfulness & & .17 & .05 & 2.76 & 01 & \\
\hline Vigor & \multirow{4}{*}{ Resilience } & .34 & .05 & 3.48 & .01 & \multirow{4}{*}{.21} \\
\hline Absorption & & -.09 & .05 & -1.00 & .31 & \\
\hline Concentration & & .18 & .04 & 1.99 & .04 & \\
\hline Mindfulness & & .10 & .04 & 1.41 & .16 & \\
\hline Vigor & \multirow{4}{*}{ Hope } & .46 & .05 & 5.24 & .00 & \multirow{4}{*}{.34} \\
\hline Absorption & & -.03 & .04 & -.42 & .67 & \\
\hline Concentration & & .20 & .03 & 2.54 & .01 & \\
\hline Mindfulness & & -.04 & .04 & -.72 & .47 & \\
\hline Vigor & \multirow{4}{*}{ Self-efficacy } & .64 & .05 & 8.13 & .00 & \multirow{4}{*}{.47} \\
\hline Absorption & & -.20 & .04 & -2.73 & .01 & \\
\hline Concentration & & .06 & .04 & .83 & .40 & \\
\hline Mindfulness & & .22 & .03 & 3.90 & .00 & \\
\hline
\end{tabular}

Note. $\mathrm{p}<.05$.

Considering Table 4; A statistically significant effect was determined in the relationship of vigor, absorption, concentration and mindfulness with optimism, $\left(\beta_{1}=.42 ; p<.05 ; \beta_{2}=-.17\right.$; $\left.\mathrm{p}<.05 ; \beta_{3}=.29 ; \mathrm{p}<.05 ; \beta_{4}=.17 ; \mathrm{p}<.05\right)$. A statistically significant effect was determined in the relationship of vigor and concentration with resilience, $\left(\beta_{5}=.34 ; \mathrm{p}<.05 ; \beta_{7}=.18 ; \mathrm{p}\right.$ $<.05)$; It can be stated that there is no significant effect on the relationship between assimilation and mindfulness and psychological resilience $\left(\beta_{6}=-.09 ; \mathrm{p}>.05 ; \beta_{8}=.10\right.$; $\mathrm{p}>.05)$. A statistically significant effect was found in the relationship of vigor and concentration with hope, $\left(\beta_{9}=.46 ; p<.05 ; \beta_{11}=.20 ; p<.05\right)$; It was determined that there was no significant effect on the relationship between absorption and mindfulness and hope; $\left(\beta_{10}=-.03 ; p>.05 ; \beta_{12}=-.04 ; p>.05\right)$. It was determined that there was a significant effect on the relationship of vigor, absorption and conscious awareness with self-efficacy, $\left(\beta_{13}=.64\right.$; $\left.\mathrm{p}<.05 ; \beta_{14}=-.20 \mathrm{p}<.05 ; \beta_{16}=.22 ; \mathrm{p}<.05\right)$. However, it can be said that there is no significant effect on the relationship between concentration and self-efficacy $\left(\beta_{15}=.06\right.$; $p>.05)$. Also; It was concluded that $37 \%$ of optimism, $21 \%$ of psychological resilience, $34 \%$ of hope and $47 \%$ of self-efficacy were explained by vigor, absorption, concentration and 
mindfulness.

\section{Discussion and Conclusion}

The purpose of organizational behavior is to try to understand the individual and group behavior within the organization. The goal is to contribute to increasing organizational effectiveness, productivity and performance. Employees' level of work engagement and mindfulness is important in terms of positive organizational behavior and organizational performance. Therefore, the aim of the study was to determine to what extent the level of work engagement and mindfulness, which are deemed necessary for the effectiveness and efficiency of the organization as well as its sustainability, had an effect on the behaviors exhibited in the organization. In line with this purpose, data were collected from a total of 203 participants, 73 females (36.0\%) and 130 males (64.0\%) working in different positions and levels in the Ministry of Youth and Sports in September 2020. 21 of the participants were high school (10.3\%), 149 (73.4) undergraduate, 31 (15.3\%) graduate and $2(1.0 \%)$ doctoral program graduates. Also; 72 (35.5\%) were officers, 28 (13.8\%) were managers, 74 (36.5\%) were trainers and $29(14.3 \%)$ were in the sports training specialist staff. The average age of the participants was $9.38 \pm 7.54$ and the average age was $36.87 \pm 7.58$.

Considering the participants' mean scores of the Work Engagement Scale $(\bar{x}=5.56)$, it can be said that their level of work engagement was quite high. According to the mean scores of the Mindfulness Scale $(\overline{\mathrm{x}}=4.33)$, the Positive Organizational Behavior Scale $(\overline{\mathrm{x}}=3.81)$ and "optimism" ( $\overline{\mathrm{x}}=3.80)$, "psychological resilience" $(\overline{\mathrm{x}}=3.49)$, "hope" $(\overline{\mathrm{x}}=4.06)$ and "self-efficacy" ( $\bar{x}=3.89)$, it can be stated that the participants have a high level of conscious awareness and an acceptable level of positive organizational behavior. According to this finding, it is possible to say that employees are aware of their qualities, that they can approach problems with a positive perspective and produce different solutions, and that they work with great desire by giving all their attention to their work and using all their potential. On the other hand, high dedication allows for the correct and proper use of time, energy and attention. This is important in terms of saving and success in the organization.

When the field of organizational behavior is examined, it is seen that there are topics such as emotion, attitude, perception, motivation, job design, conflict, negotiation, power, leadership, communication, organizational culture, job satisfaction, organizational commitment and organizational change (Bay \& Akpınar, 2016; Bay, Akpınar, \& Selamet, 2018; Coşkun \& Tabak, 2017: 102; Güngör \& Yenel, 2017; Robbins \& Judge, 2010: 9-10; Uğur \& Çolakoğlu, 2019). Therefore, it can be stated that the positive organizational behavior levels of the employees are necessary and important in terms of directing many positive outcomes about the organization.

When Table 3 regarding the relationships between variables was examined; A positive and moderate relationship was determined between "vigor" and "optimism", "psychological resilience", "self-efficacy" and "conscious awareness". A positive and moderate level relationship was determined between "absorption", "optimism" and "hope". A low-level positive correlation was found with "psychological resilience", "self-efficacy" and "mindfulness". A positive and moderate relationship was determined between 
"concentration" and "optimism", "psychological resilience", "hope" and "self-efficacy". Also; It was determined that there was a positive and low-level relationship between "concentration" and "mindfulness". Between "mindfulness", "optimism" and "self-efficacy" positive and moderate level relationship and a low-level positive relationship was determined with "resilience" and "hope". According to this result, it can be stated that there was a positive relationship between all sub-dimensions of the three scales at medium and low-levels. In other words, as the level of work engagement and mindfulness of employees increases, the probability of exhibiting positive organizational behavior increases.

Considering the results of multiple regression analysis (Table 4) regarding the prediction of organizational behavior; A statistically significant effect was determined between all sub-dimensions of work engagement (vigor, absorption, concentration), mindfulness and optimism sub-dimension of organizational behavior, $\left(\beta_{1}=.42 ; \mathrm{p}<.05 ; \beta_{2}=-.17 ; \mathrm{p}<.05 ; \beta_{3}\right.$ $\left.=.29 ; \mathrm{p}<.05 ; \beta_{4}=.17 ; \mathrm{p}<.05\right)$. According to this finding, employees doing their job enthusiastically and paying full attention to their works cause them to evaluate the events positively and to be interested only in their work.

A statistically significant relationship was determined between vigor, concentration and resilience $\left(\beta_{5}=.34 ; p<.05 ; \beta_{7}=.18 ; p<.05\right)$, and hope $\left(\beta_{9}=.46 ; p<.05 ; \beta_{11}=.20 ; p<.05\right)$. It can be stated that there was no significant effect in the relationship of resilience $\left(\beta_{6}=-.09\right.$; $\left.p>.05 ; \beta_{8}=.10 ; p>.05\right)$ and hope $\left(\beta_{10}=-.03 ; p>.05 ; \beta_{12}=-.04 ; p>.05\right)$ between abortion and mindfulness. It was determined that there was a significant effect on the relationship of vigor, assimilation and mindfulness with self-efficacy, $\left(\beta_{13}=.64 ; p<.05 ; \beta_{14}=-.20 ; p<.05\right.$; $\left.\beta_{16}=.22 ; p<.05\right)$. However, it can be said that there was no significant effect on the relationship between concentration and self-efficacy $\left(\beta_{15}=.06 ; \mathrm{p}>.05\right)$. Also it was concluded that $37 \%$ of optimism, $21 \%$ of psychological resilience, $34 \%$ of hope and $47 \%$ of self-efficacy were explained by vigor, assimilation, concentration and conscious awareness. As a result, $47 \%$ of organizational behavior can be explained by work engagement and mindfulness.

Gunesekara and Zhang (2018) examined the impact of different aspects of mindfulness on work engagement. Parallel to this study, a positive relationship was found between conscious awareness and work engagement. In addition, in this study, mindfulness consists of four dimensions (awareness, attention, focus, attitude) (Bishop et al., 2004; Feldman et al., 2007). Thanks to these dimensions, employees work with all their energies by focusing on the work environment, giving their full attention to work, and accepting even challenging tasks as they are thanks to their ability to effectively regulate emotions (Gunesekara \& Zhang, 2018: 194). Organizational success (Malinowski \& Lim, 2015), job satisfaction (Rayton \& Yalabik, 2014), organizational commitment (İbrahim \& Al Falasi, 2014) are stated as outcomes of work engagement. According to Gunesekara and Zhang (2018), the reason why work engagement is considered as a factor that increases organizational success (Ghadi et al., 2013) is attributed to employees focusing on their work and trying to do their duties in the best way (Kahn, 1990: 700). In the literature, there are also studies that deal with mindfulness as a single dimension in parallel with this study (Brown \& Ryan, 2003; Dane \& Brummel, 2013; Leroy et al., 2013; Reb et al., 2014; Thompson \& Waltz, 2007). Mindfulness is used as a therapy and treatment 
method to reduce stress and overcome problems that cause depression (Segal, Williams, \& Teasdale, 2013). According to the literature, high level of conscious awareness brings about better mental health and relationship satisfaction (Brown, Ryan, \& Creswell, 2007), and provides easier coping with problems (Falkenstrom, 2010). Individuals with a high level of mindfulness can use the power of reflection or empathy well, and they can better understand the emotions of others and arrange their own mood accordingly (Reb et al., 2014). Therefore, it is an expected result that individuals with a high level of conscious awareness show positive organizational behavior. In addition, individuals with high conscious awareness are concerned with the present time, not focusing on the past or the future. Thus, they can achieve high success and performance by focusing more on fulfilling their current responsibilities.

Mindfulness has a positive effect on psychological well-being (Brown \& Ryan, 2003; Falkenstrom, 2010; Howell et al., 2008). Therefore, high mindfulness will contribute to being more moderate and positive in relationships and behaviors.

In parallel with the results of this study, mindfulness contributes to mental, spiritual and emotional well-being (Flugel-Colle, Vincent, Cha, Laura, Bauer, \& Wahner-Roedler, 2009), increases self-regulation skills (Brown \& Ryan, 2003), positively affects empathy (Güngör, Kurtipek, \& Tolukan, 2020) and decreases the distress (Carmody \& Baer, 2008). (Gunesekara \& Zhang, 2018; Leroy et al., 2013; Malinowski \& Lim, 2015) found that employees with high mindfulness are more committed to their work. For this reason, it is recommended to employ people with high level of mindfulness or to expand the practices and studies aimed at improving the mindfulness levels of existing employees.

Attention and focus, which are important dimensions of conscious awareness, are important in terms of supporting employees to devote themselves to their jobs. Accepting the relationships without judgment facilitates adaptation to changing conditions and makes it easier to overcome problems faster. We can say that it strengthens business relations.

In the literature, it is stated that conscious awareness decreases anxiety level and contributes to emotion regulation (Kısmetoğlu, 2019), increases resilience (Yavuz, 2019) and subjective well-being (Y1lmam, 2019), increases optimism and life satisfaction (Özdoğan, 2018); It has been found to have a negative relationship with internet use (Şehidoğlu, 2014), online game addiction (Dönmez, 2018), and mobile phone addiction (Güner, 2019). According to these findings, it is seen that mindfulness leads to positive organizational behavior and is an important intervention method in reducing various types of addictions.

\section{References}

Bay, M., \& Akpınar, S. (2016). Organizational Change Management and an Emprical Study. Mehmet Akif Ersoy University Journal of Social Sciences Institute, 8(16), 61-70. https://doi.org/10.20875/sb.48748

Bay, M., Akpınar, S., \& Selamet, A. A. (2018). Yenilik yönetimini etkileyen örgütsel faktörler: Belediye ve kaymakamlik karşılaştırılması. Gazi Üniversitesi Sosyal Bilimler Dergisi, 5(14), 392-405. 
Bishop, S. R., Lau, M., Shapiro, S., Carlson, L., Anderson, N. D., Carmody, J., ... Devins, G. (2004). Mindfulness: A Proposed Operational Definition. Clinical Psychology: Science and Practice, 11(3), 230-241. https://doi.org/10.1093/clipsy/bph077

Bratton, J. (2015). Introduction to Work and Organizational Behavior (3rd ed.). Palgrave Mcmillan, New York.

Brown, K. W. \& Ryan, R. M. (2003). The benefits of being present: mindfulness and its role in psychological well-being. Journal of Personality and Social Psychology, 84(4), 822-848. https://doi.org/10.1037/0022-3514.84.4.822

Brown, K. W., Ryan, R. M., \& Creswell, J. D. (2007). Mindfulness: Theoretical foundations and evidence for its salutary effects. Psychological Inquiry, 18, 211-237. https://doi.org/ $10.1080 / 10478400701598298$

Carmody, J., \& Baer, R. A. (2008). Relationships between mindfulness practice and levels of mindfulness, medical and psychological symptoms and well-being in a mindfulness based stress reduction program. Journal of Behavioral Medicine, 31, 23-33. https://doi.org/10.1007/ s10865-007-9130-7

Dane, E., \& Brummel, B. J. (2013). Examining workplace mindfulness and its relations to job performance and turnover intention. Human Relations, 67(1), 105-128. https://doi.org/ $10.1177 / 0018726713487753$

Falkenström, F. (2010). Studying mindfulness in experienced meditators: A quasi-experimental approach. Personality and Individual Differences, 48(3), 305-310. https://doi.org/10.1016/j.paid.2009.10.022

Flugel Colle, K. F., Vincent, A., Cha, S. S., Loehrer, L. L., Bauer, B. A., \& Wahner-Roedler, D. L. (2010). Measurement of quality of life and participant experience with the mindfulness-based stress reduction program. Complementary Therapies in Clinical Practice, 16(1), 36-40. https://doi.org/10.1016/j.ctcp.2009.06.008

Gilbert, P. (2005). Compassion: Conceptualizations, Research and use in psychotheraphy (p. 245). New York: Brunner Routge. https://doi.org/10.4324/9780203003459

Griffin, R. W., \& Moorhead, G. (2011). Organizational behavior: Managing people and organizations (10th ed.). Cengage Learning.

Güler, B. K. (2009). Pozitif Psikolojik Sermaye: Tanımı, Bileşenleri ve Yönetimi. In A. Keser, G. Yılmaz, \& S. Yürür (Eds.), Çalışma Yaşamında Davranış: Güncel Yaklaşımlar Örgütsel Davranış Içinde. Umuttepe Yayınları, Kocaeli.

Güner, U. (2019). Ortaöğretim kurumları öğrencilerinin cep telefonu bă̆ımlılı̆̆ının yordayıcısı olarak bilinçli farkındalık (Yüksek lisans tezi, Ondokuz Mayıs Üniversitesi, Samsun).

Güngör, N. B., \& Yenel, F. (2017). Beden eğitimi ve spor öğretmenliği bölümü öğrencilerinin epistemolojik inançlari ile liderlik özellikleri arasindaki ilişkinin incelenmesi. Beden Ĕ̆itimi 
ve Spor Bilimleri Dergisi, 19(2), 39-55.

Güngör, N. B., Kurtipek, S., \& Tolukan, E. (2020). The effect of mindfulness of physical education and sports teacher candidates on empathic tendency. International Journal of Psychology and Educational Studies, 7(4), 132-142. https://doi.org/10.17220/ijpes.2020. 04.012

Gürbüz, S., \& Sığrı, Ü. (2015). Örgütsel davranışa giriş: Yönetim bilimi ve örgütsel davranış alanının kuramsal gelişimi. In Ü. Sığrı, \& S. Gürbüz (Eds.), Örgütsel Davranış Içinde (pp. 1-44). İstanbul: Beta Basım Yayım Dağıtım.

Howell, A. J., Digdon, N. L., Buro, K., \& Sheptycki, A. R. (2008). Relations among mindfulness, well-being, and sleep. Personality and Individual Differences, 45, 773-777. https://doi.org/10.1016/j.paid.2008.08.005

Ibrahim, I., \& Al Falasi, S. (2014). Employee loyalty and engagement in UAE public sector. Employee Relations, 36(5), 562-582. https://doi.org/10.1108/ER-07-2013-0098

Kabat-Zinn, J. (2005). Coming to Our Senses: Healing Ourselves and The World Through Mindfulness. New York, Hyperion.

Kaçay, Z., \& Soyer, F., (2020). İş Yeri Yılmazlı̆̆ının Yordayıcıları: Örgütsel Güven, Lider-Üye Etkileşimi ve İş Yeri Maneviyatı. LAP LAMBERT Academic Publishing.

Karasar, N. (2013). Bilimsel Araştırma Yöntemi (25th ed.). Nobel Yayınc1lı, Ankara.

Kaygın, E., \& Kosa, G. (2020). Olumsuz boyutlarıyla örgütsel davranış. Eğitim Yayınevi. Konya.

Kırpık, E. (2020). Örgütsel Davraniş Çalişmalarinda Yeni Kavramlar: Google Akademik (2019) Ve Sci (2020) Veri Tabanlarina Yönelik Sistematik Literatür Taramasi. In M. Avc1, \& E. Kara (Eds.), Örgütsel davranış üzerine güncel çalışmalar içinde (p. 13). İstanbul: Hiper Yayin.

Kısmetoğlu, G., (2019). 15-18 yaş arası ergenlerde duygu düzenleme ve bilinçli farkındalık becerilerinin kaygl düzeyleri ile ilişkisinin incelenmesi (Yüksek lisans tezi, Gelişim Üniversitesi, İstanbul).

Koçel, T. (1999). İşletme Yöneticiliği. İstanbul, Beta Yayımları.

Kurtipek, S., Güngör, N. B., Esentürk, O. K., \& Tolukan, E. (2020). The mediating role of nutrition knowledge level in the effect of mindfulness on healthy nutrition obsession. Progress in Nutrition, 22(1), 138-145. https://doi.org/10.23751/pn.v22i1-S.9807

Leroy, H., Frederik, A., Dimitrova, N. G., \& Sels, L. (2013). Mindfulness, authentic functioning, and work engagement: A growth modelling approach. Journal of Vocational Behaviour, 82(3), 238-247. https://doi.org/10.1016/j.jvb.2013.01.012

Luthans, F., Avolio, B. J., Avey, J. B., \& Norman, S. M. (2007). Positive psychological capital: Measurement and relationship with performance and satisfaction. Personnel Psychology, 
60(3), 541-572. https://doi.org/10.1111/j.1744-6570.2007.00083.x

Luthans, F., Norman, S. M., Avolı, B. J., \& Avey, J. B. (2008). The Mediating Role of Psychological Capital in the Supportive Organizational Climate-Employee Performance Relationship. Journal of Organizational Behavior, 29, 219-238. https://doi.org/10.1002/ job.507

Malinowski, P., \& Lim, H. J. (2015). Mindfulness at work: positive affect, hope, and optimism mediate the relationship between dispositional mindfulness, work engagement, and well-being. Mindfulness, 6(6), 1250-1262. https://doi.org/10.1007/s12671-015-0388-5

Moore, A., \& Malinowski, P. (2009). Meditation, mindfulness and cognitive flexibility. Consciousness and Cognition, 18(1), 176-186. https://doi.org/10.1016/j.concog.2008.12.008

Mowday, R. T., \& Sutton, R. I. (1993). Organizational Behavior: Linking Individuals and Groups to Organizational Contexts. Annual Review of Psychology, 44(1), 195-229. https://doi.org/10.1146/annurev.ps.44.020193.001211

Özdoğan, H. (2018). Yetişkinlerin bilinçli farkındalık düzeylerinin iyimserlik ve yaşam doyumlarına etkisi (Yüksek lisans tezi, Ondokuz Mayıs Üniversitesi, Samsun).

Özyeşil, Z., Arslan, C., Kesici, Ş., \& Deniz, M. E. (2011). Bilinçli Farkındalık Ölçeği'ni Türkçeye uyarlama çalışması. Eğitim ve Bilim, 36(160), 224-235.

Rayton, B. A., \& Yalabik, Z. Y. (2014). Work engagement, psychological contract breach and job satisfaction. The International Journal of Human Resource Management, 25(17), 2382-2400. https://doi.org/10.1080/09585192.2013.876440

Reb, J., Narayanan, J., \& Chaturvedi, S. (2014). Leading mindfully: Two studies on the influence of supervisor trait mindfulness on employee well-being and performance. Mindfulness, 5, 36-45. https://doi.org/10.1007/s12671-012-0144-z

Robbins, S. P., \& Judge, T. A. (2010). Organizational Behavior (14th ed.). Pearson College Division.

Schaufeli, W. B., \& Bakker, A. B. (2003). UWES-Utrecht Work Engagement Scale: Test Manual (Unpublished Manuscript, Department of Psychology, Utrecht University, Utrecht). https://doi.org/10.1037/t76451-000

Schaufeli, W. B., Salanova, M., Gronzález-Romá, V., \& Bakker, A. B. (2002). The measurement of engagement and burnout: A two sample confirmatory factor analytic approach. Journal of Happiness Studies, 3(1), 71-92. https://doi.org/10.1023/A:10156309 30326

Segal, Z. V., Williams, J. M., \& Teasdale, J. D. (2013). Mindfulness-based cognitive therapy for depression (2nd ed.). New York: Guilford.

Şehidoğlu, Z. (2014). 15-17 yaş grubu ergenlerde bilinçli farkındalık düzeyi ile problemli internet kullanımı arasındaki ilişkinin incelenmesi (Yüksek lisans tezi,Üsküdar Üniversitesi, İstanbul). 


\section{Macrothink}

Sims, R. R. (2002). Managing organizational behavior. Westport: Quorum Books.

Tabachnick, B. G., \& Fidell, L. S. (2013). Using multivariate statistics. CA: California State University.

Thera, N. (2008). The Power of Mindfulness. Kanday, Sri Lanka, Wheel Publication.

Thompson, B. L., \& Waltz, J. (2007). Everyday mindfulness and mindfulness meditation: overlapping constructs or not? Personality and Individual Differences, 43(7), 1875-1885. https://doi.org/10.1016/j.paid.2007.06.017

Uğur, O. A., \& Çolakoğlu, T. (2019). Analyzing the relationship between physical education teachers'leadership behaviors and their communication skills (The case of Ankara). Journal of International Social Research, 12(65), 892-898. https://doi.org/10.17719/jisr.2019.3502

Yavuz, B. (2019). Öğretmen adaylarında psikolojik dayanıklılık ve bilinçli farkındalık arasındaki ilişki: Manevi iyi oluşun rolü (Yüksek lisans tezi, Sabahattin Zaim Üniversitesi, İstanbul).

Y1lmam, B. (2019). Bilinçli farkındalık ve öz-duyarlılı̆̆ın öznel iyi oluş üzerindeki etkisi (Yüksek lisans tezi,Üsküdar Üniversitesi, İstanbul).

\section{Copyright Disclaimer}

Copyright for this article is retained by the author(s), with first publication rights granted to the journal.

This is an open-access article distributed under the terms and conditions of the Creative Commons Attribution license (http://creativecommons.org/licenses/by/3.0/). 